\title{
Prevention of unfavourable effects of cigarette smoke on flap viability using botulinum toxin in random pattern flaps: An experimental study
}

\author{
Hikmet Karayel MD¹, Burak Kaya MD², Muzaffer Caydere MD $^{3}$, Ahmet Terzioğlu MD¹, Gürcan Aslan MD¹
}

H Karayel, B Kaya, M Caydere, A Terzioglu, G Aslan. Prevention of unfavourable effects of cigarette smoke on flap viability using botulinum toxin in random pattern flaps: An experimental study. Plast Surg 2015;23(3):177-182.

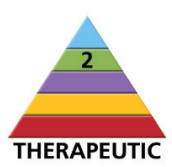

BACKGROUND: There are numerous clinical and experimental studies reporting unfavourable effects of cigarette smoke on skin flaps.

OBJECTIVE: To investigate whether unfavourable effects of cigarette smoke on flap survival could be reduced by botulinum toxin type A.

METHODS: Twenty-eight male Wistar albino rats (15 months of age, mean weight $210 \mathrm{~g}$ [range $180 \mathrm{~g}$ to $230 \mathrm{~g}$ ]) were included. They were divided into four groups of seven animals each. The control group underwent the surgical procedure alone. Surgical procedure was performed after administration of botulinum toxin type $\mathrm{A}$ in the botulinum toxin (BTX) group, after exposure to cigarette smoke in the cigarette smoke (CS) group, and after BTX type A administration and exposure to CS in the CS+BTX (CS+BTX) group. Random pattern cutaneous flaps $(3 \mathrm{~cm} \times 9 \mathrm{~cm})$ were elevated from the dorsum of all rats. Necrosis area was calculated in percentages (\%) using Image J computer software. Tissue samples were examined histopathologically.

RESULTS: The mean necrotic area in the control group (26\%) and in the BTX group $(21 \%)$ were similar $(\mathrm{P}=0.497)$, whereas administration of BTX type A significantly decreased flap necrosis area in the rats exposed to CS (the mean necrosis areas were $41.5 \%$ in the CS group, and $26 \%$ in the $\mathrm{CS}+\mathrm{BTX}$ group; $\mathrm{P}<0.001)$. Histopathological examination findings corroborated the unfavourable effects of CS and preventive effects of BTX type A.

CONCLUSION: Preoperative administration of BTX significantly enhanced flap viability in the rats exposed to CS. Further human studies are warranted to verify whether BTX type A could be used as an agent to reduce the risk of flap necrosis in patients who smoke.

Key Words: Botulinum toxin type A; Flap; Flap survival; Smoking

\author{
La prévention des effets défavorables de la fumée \\ de cigarette sur la viabilité de lambeaux aléatoires \\ au moyen de la toxine botulique : une étude \\ expérimentale
}

HISTORIQUE : De nombreuses études cliniques et expérimentales font état des effets défavorables de la fumée de cigarette (FC) sur les lambeaux cutanés.

OBJECTIF : Examiner s'il est possible de réduire les effets défavorables de la FC sur la survie des lambeaux grâce à la toxine botulique (TXB) de type A. MÉTHODOLOGIE : Vingt-huit rats albinos Wistar (15 mois, poids moyen de $210 \mathrm{~g}$ [plage de $180 \mathrm{~g}$ à $230 \mathrm{~g}$ ]) ont participé à l'étude. Ils ont été répartis en quatre groupes de sept animaux. Le groupe témoin a subi seulement l'intervention chirurgicale. Après l'intervention, le groupe TXB a reçu de la TXB de type $\mathrm{A}$, le groupe $\mathrm{FC}$ a été exposé à la $\mathrm{FC}$ et le groupe FC+TXB s'est fait administrer de la TXB de type A et a été exposé à la FC. Les chercheurs ont prélevé des lambeaux cutanés prélevés de manière aléatoire $(3 \mathrm{~cm} \times 9 \mathrm{~cm})$ sur le dos de tous les rats. Ils ont calculé les zones nécrotiques en pourcentages (\%) au moyen du logiciel ImageJ et fait l'examen histopathologique des échantillons de tissu.

RÉSULTATS : Les zones nécrotiques moyennes étaient similaires dans le groupe témoin (26\%) et le groupe TXB (21\%) ( $\mathrm{P}=0,497)$, mais l'administration de TXB de type A réduisait considérablement les zones nécrotiques des lambeaux chez les rats exposés à la $\mathrm{FC}$ (zones nécrotiques moyennes de $41,5 \%$ dans le groupe FC et de $26 \%$ dans le groupe $\mathrm{FC}+\mathrm{TXB} ; \mathrm{P}<0,001)$. Les résultats de l'examen histopathologique corroboraient les effets défavorables de la FC et les effets préventifs de la TXB de type A.

CONCLUSION : L’administration préopératoire de TXB améliore considérablement la viabilité des lambeaux chez les rats exposés à la FC. Il faudra réaliser d'autres études sur des humains pour vérifier si la TXB de type A peut être utilisée pour réduire le risque de nécrose des lambeaux chez les patients fumeurs.

Partial or complete flap loss has plastic surgeons seeking interventions that may decrease the amount of distal flap ischemia and subsequent flap necrosis. Chemical or surgical delay procedures are among the most common interventions $(4,5)$. Many agents that enhance or reduce flap viability have been reported in the literature. Investigated agents improving flap viability include agents suppressing free radical production $(6,7)$, nitric oxide $(8,9)$, sildenafil $(10,11)$, vascular endothelial growth factor (12) and vasonatrin peptide (13).

Unfavourable effects of smoking on wound healing and flap necrosis are well known. Many studies in the literature have demonstrated that cigarettes and nicotine enhance the rate of necrosis in random pattern flaps (14-22). Possible reasons for smoking to cause necrosis in skin flaps are both multifunctional and complex. Carbon monoxide binds to the hemoglobin molecule where oxygen is supposed to bind and, thus, displaces oxygen. Moreover, affinity of carbon monoxide to hemoglobin is 250 times greater than that of oxygen (23). Blood of positioning, hematoma).

\footnotetext{
${ }^{1}$ Department of Plastic, Reconstructive and Aesthetic Surgery, Ankara Training and Research Hospital; ${ }^{2}$ Department of Plastic, Reconstructive and Aesthetic Surgery, Ankara University Faculty of Medicine; ${ }^{3}$ Department of Pathology, Ankara Training and Research Hospital, Ankara, Turkey

Correspondence: Dr Burak Kaya, Ankara Üniversitesi Tıp Fakültesi Cebeci Hastanesi, Plastik Rekonstrüktif ve Estetik Cerrahi A.D., 06590, Dikimevi, Ankara, Turkey. Telephone 90-312-595-6632, fax 90-312-595-6563, e-mail drburak@yahoo.com
} 


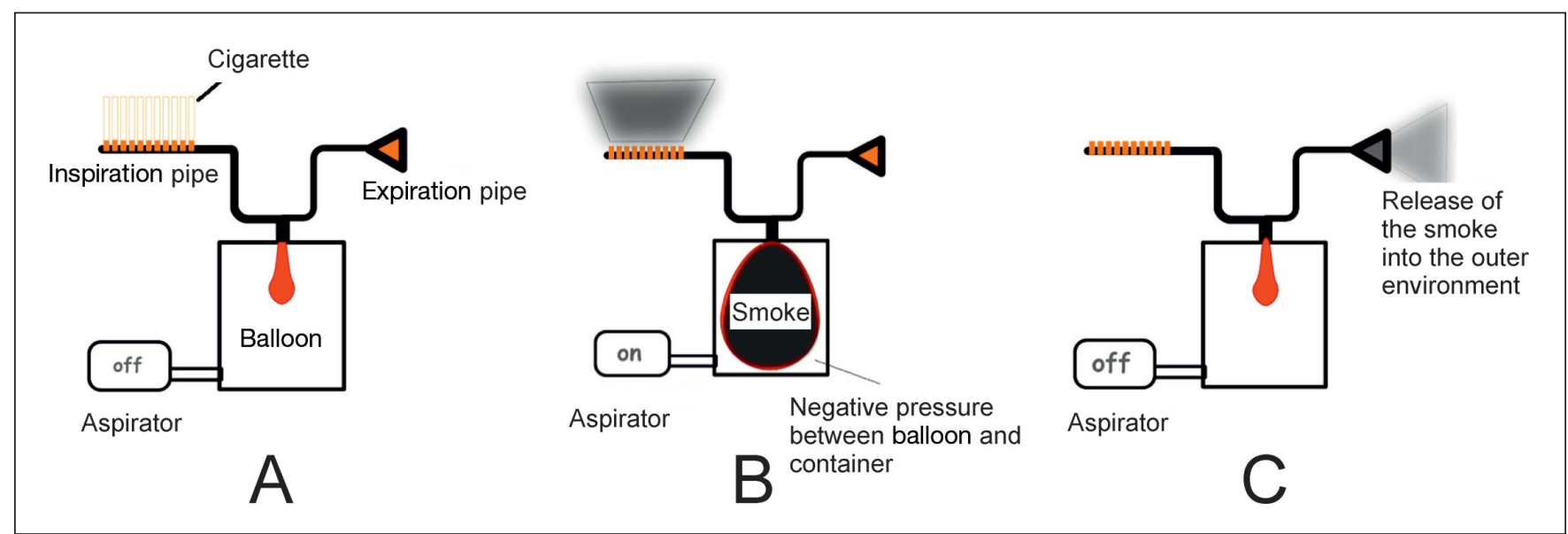

Figure 1) Diagram of the smoking simulator. A Aspirator is turned off. B The balloon is filled with smoke when the aspirator is turned on. C Release of smoke into environment as the aspirator is turned off

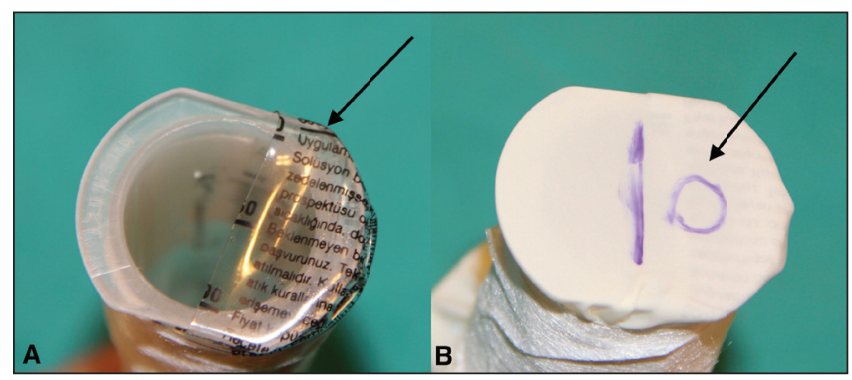

Figure 2) A Serum container that covers 50\% of the pipe (arrow). B Finger from a glove is spread over the pipe and cut in the form of a valve (arrow)

smokers coagulates more easily compared with that of nonsmokers (24-26). Nicotine in cigarettes is a strong vasoconstrictor and, thereby, reduces skin blood flow by $30 \%$ to $40 \%(27,28)$. In addition, nicotine alters the prostacyclin/thromboxane balance. Accordingly, thrombocyte activation and aggregation are enhanced, which is considered to be responsible for many complications associated with cigarettes and nicotine $(29,30)$. Nicotine also has unfavourable effects on blood flow by increasing hematocrit and blood viscosity, decreasing the deformation ability of erythrocytes and increasing fibrinogen (30-32).

In recent years, botulinum toxin (BTX) has been used in different areas of medicine for medical and cosmetic purposes. Medically, BTX is used for the treatment of many diseases including blepharospasm, spasmodic torticollis, extremity dystonia and hemifacial spasm. In addition, it is used for the treatment of palmar and axillary hyperhidrosis caused by autonomous nervous system hyperactivity (33-36). Physiologically, BTX irreversibly binds to presynaptic neurons at the neuromuscular junction and inhibits the release of acetylcholine that causes muscle relaxation (37). It has been shown that BTX inhibits the release of neurotransmitters and neuropeptides other than acetylcholine, including norepinephrine (NE), which causes vasodilation by sympatholysis $(38,39)$. The significant vasodilator effect of BTX has also been shown by Clemens et al (40). Vasoconstriction is proposed to be one of the most important effects of cigarette smoking jeopardizing flap viability, and is shown to be reversed by vasodilator administration (41). BTX prevents vasoconstriction, and its sympatholytic activity leads to an increase in skin microcirculation (42). The present study was designed to investigate whether pretreatment of a flap pedicle with BTX neutralizes the unfavourable effects of cigarette smoking on flap viability by its vasodilator and sympatholytic activity. Overall, BTX could be an advantageous pharmacological agent to prevent many unfavourable effects of cigarettes owing to its high local activity and low systemic effects.

\section{METHODS}

Experimental animals

The present study included 28 male Wistar albino rats (15 months of age, mean weight $210 \mathrm{~g}$ [range $180 \mathrm{~g}$ to $230 \mathrm{~g}$ ]). The study was approved by the Animal Experiments Ethics Committee of Ankara Training and Research Hospital (Ankara, Turkey). Experimental animals were housed at a room temperature of $18^{\circ} \mathrm{C}$ to $20^{\circ} \mathrm{C}$. Because the effects of estrogen on flap circulation are known $(43,44)$, female rats were not included.

Experimental animals were divided into four groups of seven rats. Standard McFarland flaps were elevated on the dorsum of each rat. The control group consisted of rats undergoing surgery alone. The BTX group consisted of rats undergoing surgery after BTX administration. In this group, impact of BTX on flap survival was investigated. The cigarette smoking (CS) group consisted of rats undergoing surgery after exposure to cigarette smoke. In this group, the effect of smoking on flap necrosis rate was investigated. The BTX+CS group consisted of rats undergoing surgery after BTX administration and exposure to cigarette smoke. In this group, the effects of BTX administration on flaps exposed to preoperative smoking was investigated.

\section{BTX and CS}

A Botox (Allergan, Ireland) flacon contains sterile lyophilized $100 \mathrm{U}$ clostridium BTX type A-hemagglutinin complex, $0.5 \mathrm{mg}$ human albumin and $0.9 \mathrm{mg}$ sodium chloride. A $2 \mathrm{U} / 0.1 \mathrm{~mL}$ Botox was prepared by adding $5 \mathrm{~mL}$ preservative-free sterile normal saline $(0.9 \%$ sodium chloride for injection). Two units of BTX was administered into the centre of the proximal one-third of the McFarlane flap, one week before elevation of the flap.

In the present study, 2R1 cigarettes were used based on the Kentucky University Tobacco criteria $(45,46)$. A device designed to mimic human physiology was used (Figure 1) and experimental animals were exposed to smoke. The space between the external surface of the balloon and the internal part of container represented pleural space (Figure 1A). The balloon was inflated via an aspirator by creating negative pressure outside the balloon, which was filled with smoke from a burning cigarette (mimicking inspiration) (Figure 1B). When the aspirator was off, the smoke in the balloon was released through the other end of the device (the expiration pipe) into the outer environment (Figure 1C).

The tube releasing the smoke into the outer environment was designed to represent the last point (mouth and nose) of the human respiratory system. The difficulty in designing the device was providing a single direction for the cigarette smoke; ie, smokers inhale smoke into their lungs through oral route and expel this inhaled smoke via oral and nasal routes. For this purpose, two one-way valves that mimicked the 


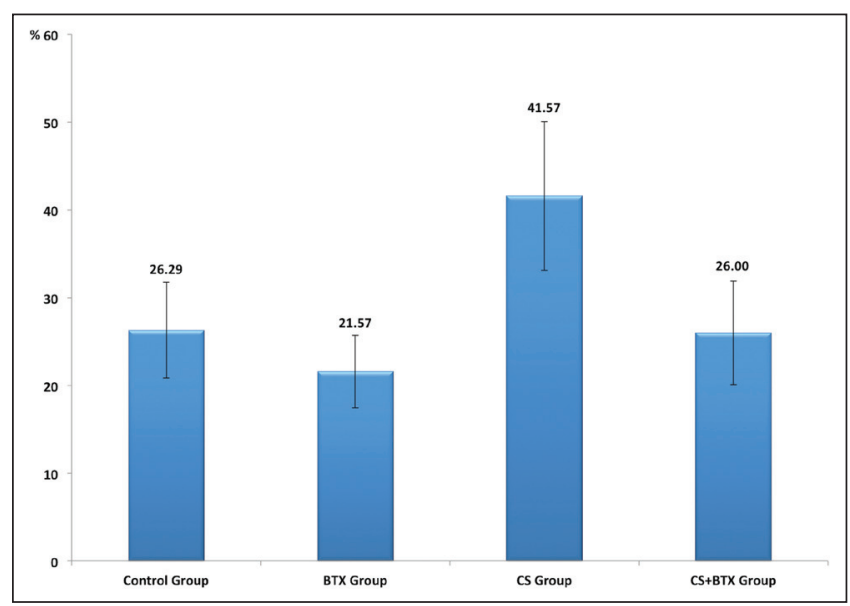

Figure 3) Mean necrosis areas in the study groups. BTX Botulinum toxin; CS Cigarette smoke

nose and mouth were designed. While the balloon was being inflated, it inhaled the smoke by means of the one-way valve and released the smoke by means of the second one-way valve during expiration. To create a valve, $50 \%$ of the pipe was covered by a serum container. The finger part of a glove was cut and spread over the container. The area on the finger glove marked as 'D' was cut (Figure 2).

The air in the pipe was easily expelled by pushing the glove, but the glove adhered to the serum container and prevented the air from reentering. One valve was located in the expiration pipe and the other in the inspiration pipe, to carry the smoke in a single direction.

In the groups that were exposed to smoke, application was performed for $10 \mathrm{~min}$ twice a day, for 14 days. While lighting cigarettes, the device was turned on and the expiration pipe was placed in the cage. The cage was covered with inflammable fabric, and aluminum foil was placed on the base of the cages so that the cigarette ash would not harm the animals.

To assess the efficacy of the smoking simulator, carboxyhemoglobin levels were measured by adding $0.25 \mathrm{~mL}$ venous blood into a $1 \mathrm{~mL}$ heparinized arterial blood gas tube. Smoking was considered to be effective when carboxyhemoglobin levels were between 15\% and 20\% (46).

\section{Surgical method}

The rats were anesthetized via an intramuscular injection of ketamine hydrochloride $(30 \mathrm{mg} / \mathrm{kg})$ and placed prone on the operating table; all four extremities were secured. Depth of anesthesia was assessed based on chin and skeletal muscle tonus. The dorsal hair of the rats were shaved and the surgical field was appropriately cleaned using polyvinylpyrrolidone iodine (1000 mL Batticon Sol, Adeka, Turkey). A standard McFarlane $3 \mathrm{~cm} \times 9 \mathrm{~cm}$ flap was drawn with a distal pedicle. Subsequently, the caudally based flap, which was modified according to Khouri et al (47), was incised using a number 15 surgical blade. The flap included all skin layers and the panniculus carnosus, and was elevated by blunt dissection. After hemostasis, the flap was sutured to its original position by continuous suture using 4/0 silk. All procedures were performed in accordance with the rules of asepsis. In the event that the rats urinated or defecated in the course of surgery, maintenance of anesthesia was provided by readministering one-third of the original dose of the anesthetic agent.

The animals were awoken and placed in separate cages to avoid damaging one another's flap.

\section{Clinical and histopathological evaluation}

For clinical evaluation, the ratio of the necrotic area (area with colour change, dry scar formation and lack of bleeding) to viable tissue within the $3 \mathrm{~cm} \times 9 \mathrm{~cm}$ flap area was determined. For this purpose, flaps were
TABLE 1

Mean necrosis areas of the groups

\begin{tabular}{lcc}
\hline Group & $\begin{array}{c}\text { Necrosis area, \%, } \\
\text { mean } \pm \text { SD }\end{array}$ & $\mathbf{9 5 \% ~ C l ~}$ \\
\hline Control & $26.29 \pm 5.47$ & $21.23-31.34$ \\
Botulimum toxin & $21.57 \pm 4.12$ & $17.77-25.38$ \\
Cigarette smoke & $41.57 \pm 8.46$ & $33.74-49.40$ \\
Cigarette smoke + botulimum toxin & $26.00 \pm 5.92$ & $20.53-31.47$ \\
\hline
\end{tabular}

monitored on daily basis. Colour change and coldness were detected in the distal parts of the flaps on the postoperative day 2 in all groups. On postoperative day 5 , necrosis and a demarcation line became more remarkable in the distal parts of the flaps with decreased circulation. Flap areas of questionable viability were considered to be necrotic. The rats were euthanized on postoperative day 7; images were obtained using digital camera with the assistance of a tripod from equal distances using a ruler placed near the flap. Live and dead flap areas were determined (in pixels) using Image J computer program. Necrosis areas were calculated in percentages (\%). Areas of epidermolysis in the flaps were considered to be viable skin areas because they healed with epithelialization.

All flaps were harvested on postoperative day 7 and sectioned into three pieces; each piece was vertically divided into five pieces, placed in cassettes and stored in 10\% formaldehyde solution. These tissue samples were embedded into paraffin blocks after being fixed in formalin, and then $4 \mu$ sections were obtained using a microtome. They were stained with hematoxylin and eosin and examined under a light microscope. For histopathological examination, six parameters including capillary vascular proliferation, capillary collapse, artery and venule diameters, and extensiveness and localization of necrosis were investigated.

\section{Statistical analysis}

Multigroup comparison of numerical variables was performed using ANOVA test. Subgroup comparisons were performed using Tukey's honestly significant difference test; $\mathrm{P}<0.05$ was considered to be statistically significant.

\section{RESULTS}

The mean necrosis area was $26 \%$ (range $16 \%$ to $31 \%$ ) in the control group, $21 \%$ (range $17 \%$ to $29 \%$ ) in the BTX group, $41.5 \%$ (range $35 \%$ to $58 \%$ ) in the CS group and $26 \%$ (range $15 \%$ to $34 \%$ ) in the CS+BTX group (Figure 3).

There was a significant difference among the groups with regard to mean necrosis area $(\mathrm{P}<0.001)$. Paired comparison revealed that the mean necrosis area of the CS group was significantly higher than those of the control $(\mathrm{P}=0.001)$, BTX $(\mathrm{P}<0.001)$ and $\mathrm{CS}+\mathrm{BTX}$ $(\mathrm{P}<0.001)$ groups. The mean necrosis areas of the BTX group $(\mathrm{P}=0.497)$ and $\mathrm{CS}+\mathrm{BTX}$ group $(\mathrm{P}=1.000)$ were found to be similar to that of the control group. No significant difference was observed between the BTX and CS+BTX groups in terms of the mean necrosis area $(\mathrm{P}=0.549)$. The mean necrosis areas of the groups are presented in Table 1.

On histopathological examination, normal capillary proliferation was detected in the control group. In the proximal part of the flap in the BTX group, elongation was detected in the arterioles and venules, an increase was detected in the diameters of small capillaries, and there was fibroblastic activity and capillary proliferation. No vascular collapse was observed. Vascular collapse was observed in the CS group and fibroblastic proliferation was higher; moreover, macrophage and mast cell infiltration areas were detected. Histopathological findings confirmed full-thickness damage. In the CS+BTX group, no vascular collapse was observed even in the very distal part of the flap. Figure 4D illustrates a dilated vessel in the distal part of the flap. 


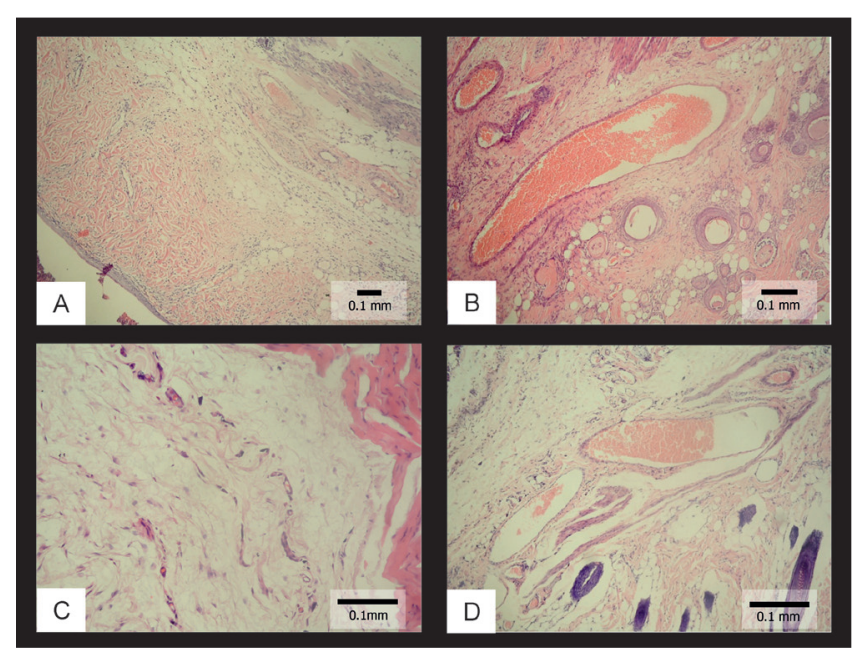

Figure 4) Histopathological views of the samples. A Normal findings in the control group (hematoxylin and eosin stain, original magnification $\times 40$ ); B Histopathological view in the botulinum toxin (BTX) group (hematoxylin and eosin stain, original magnification $\times 60$ ); C Histopathological view in the cigarette smoking (CS) group (hematoxylin and eosin stain, original magnification $\times 100$ ); D Histopathological view in the CS+BTX group (dilated vessels filled with erythrocytes) (hematoxylin and eosin stain, original magnification $\times 100$ )

Epithelial damage was more superficial in this group. Samples from histopathological examination of the groups are shown in Figure 4.

\section{DISCUSSION}

Various agents have been tried to prevent unfavourable effects of nicotine on flaps in smokers. Aker et al (48) conducted a study involving rats using pentoxifylline, a hemorheological agent, and demonstrated that intraperitoneal administration of pentoxifylline decreased flap necrosis in rats that received nicotine. Karien and Maisel (49) applied nicotine to rats and demonstrated that oral tazocin, an alpha-1 blocking agent, enhanced flap survival. Eskitascioglu and Gunay (50) conducted a study that demonstrated the benefit of vasodilatory effects and thromboxane A2 synthesis-reducing effects of prostaglandins. They found that topical prostacyclin and prostaglandin $\mathrm{E}_{1}$ enhanced flap survival in rats exposed to nicotine. Rinker et al (46) demonstrated that unfavourable effects of smoking in rats exposed to cigarette smoke could be reduced secondary to the vasodilatory effects of calcium channel blockers.

There are studies investigating the effects and mechanism of action of BTX on flap healing. Effects of BTX on autonomous nerve system and vascular smooth muscles are known. Thus, BTX has been used to treat cases of sympathetic vasoconstriction. Sycha et al (51) used a BTX type A preparation in patients with Raynaud's phenomenon. Sympathectomy enhances cutaneous blood flow; moreover, it enhances microcirculation in the muscular flaps $(52-54)$. It has been hypothesized that BTX acts as surgical sympathectomy, thus enhancing flap survival. Clemens et al (40) demonstrated that BTX caused significant vasodilation; thus, it might be used to prevent anastomotic thrombosis. Fathi et al (55) demonstrated that pretreatment with BTX type A was associated with a lower rate of arterial and venous thrombosis in a rabbit model of microanastomosis. Kim et al (42) reported that BTX type A used in random cutaneous flaps in rats enhanced the survival rates by means of selective suppression of sympathetic neurons of the cutaneous microcirculatory system. Not only NE but also a number of cotransmitters are concomitantly secreted from adrenergic nerve endings. Neuropeptide Y (NPY) and ATP are two of the important cotransmitters (56-58). In general, NE is synthesized in the small vesicles in neurons when low-frequency stimulations are applied to the sympathetic neurons. However, NE and NPY are synthesized together in large vesicles during highfrequency stimulations (59). ATP is released from both small and large vesicles (60). Soluble $\mathrm{N}$-ethylmaleimide-sensitive factor activating protein receptor (SNARE) proteins are the major regulators of these cotransmitters $(61,62)$. It is known that BTX acts on the same proteins at the synaptic membrane level. Morris et al (39) conducted a study involving guinea pigs and detected a $25 \mathrm{kDa}$ immune-reactive synaptosomal-associated protein (SNAP-25) in the inferior vena cava. Vascular stimulation by the sympathetic system initially led to vasodilation due to the effect of NE on $\beta 1$ receptors, but vasoconstriction was later observed along with the activation of alpha 2 receptors; NPY release was enhanced but BTX- and NE-originated vasoconstriction was decreased in the event of continuation of the current stimulation. They attributed this condition to SNARE proteins not having a role in the exocytosis in large vesicles, and to small and large vesicles, which were found in presynaptic membrane, having different regulation mechanisms for exocytosis. As is known, sympathetic vasoconstriction arises from alpha receptors. Phospholipase D activity plays an important role in signal conduction of alpha 2 receptors. BTX is known to decrease phospholipase D activity (63). Calcitonin-associated peptide is a potent vasodilator and also plays a role in wound healing. Studies have reported that BTX leads to an increase in the amount of calcitoninrelated peptide (64). While lower blood flow is generally expected in paralyzed muscle compared with active muscle, Matic et al (65) demonstrated increased blood flow, blood volume and surface permeability in the masseter muscle paralyzed by toxin compared with the control group. The Matic et al study suggested that BTX may be beneficial in enhancing flap survival and in reducing unfavourable effects of smoking.

In the present study, we administered BTX in random pattern flaps to benefit from its vasodilator activity. Despite a decrease in necrosis area in the group that received BTX compared with the control group, the difference was not statistically significant (21\% and 26\%, respectively $[\mathrm{P}=0.497])$. In their experimental study, Kim et al (66) elevated $3 \mathrm{~cm} \times 10 \mathrm{~cm}$ distal-based flaps from the dorsum of rats and found the ratio of intact/total flap area to be $53 \%$ in the control group and $94 \%$ in the group that received BTX. They applied a total of $20 \mathrm{U}$ of BTX into the distal, proximal and median aspects of the flap. In the present study, we applied only $2 \mathrm{U}$ of BTX into the proximal aspect of the flap. Differences between the doses and application sites may have led to the differences between the results of the present study and those of the above-mentioned study.

The effect of cigarette smoking on random flaps is irreversible even if smoking is discontinued (67). This leads to complications in smokers in clinical practice. Many problems, such as high rates of distal flap necrosis, problems in wound healing, requirement for a second surgery and higher costs, are associated with smoking. In the present study, the rate of flap necrosis was significantly higher in rats exposed to cigarette smoke than in those in the control group ( $41 \%$ versus $26 \%$; $\mathrm{P}=0.001$ ). The rate of necrosis in the group exposed to cigarette smoke and receiving BTX one week before the surgery was similar (26\%) to that of the control group. This result suggested that the unfavourable effects of smoking on flap viability may be reduced by BTX.

\section{CONCLUSION}

The results of the present study indicate that BTX applied one week before flap elevation in smokers may reduce flap necrosis rates. However, further clinical studies investigating this subject are needed in clinical practice situations.

DISCLOSURES: The authors have no financial disclosures or conflicts of interest to declare. 


\section{REFERENCES}

1. Aston SJ, Beasley RW, Thorne CH. Grabb and Smith's Plastic Surgery, 5th edn. Philadelphia: Lippincott-Raven Publishers 1997:13-25

2. Palmer B, Jurell G, Norberg KA. The blood flow in experimental skin flaps in rats studied by means of the 133 xenon clearance method. Scand J Plast Reconstr Surg 1972;6:6-12.

3. Hoopes JE. Pedicle flaps - an overview. In: Krizek TJ, ed. Symposium on Basic Science in Plastic Surgery, Vol 15. St Louis: Mosby, 1976:241-59.

4. Dhar SC, Taylor GI. The delay phenomenon: The story unfolds. Plast Reconstr Surg 1999;104:2079-91.

5. Zahir KS, Syed SA, Zink JR, Restifo RJ, Thomson JG. Ischemic preconditioning improves the survival of skin and myocutaneous flaps in a rat model. Plast Reconstr Surg 1998;102:140-50.

6. Burton GW, Ingold KU. Vitamin E: Application of the principles of physical organic chemistry to the exploration of its structure and function. Acc Chem Res 1986;19:194-201.

7. Nordmann R. Alcohol and antioxidant systems. Alcohol Alcohol 1994:29:513-22.

8. Um SC, Suzuki S, Toyokuni S, et al. Involvement of nitric oxide in survival of random pattern skin flap. Plast Reconstr Surg 1998;101:785-92.

9. Cordeiro PG, Santamaria E, Hu QY. Use of a nitric oxide precursor to protect pig myocutaneous flaps from ischemia-reperfusion injury. Plast Reconstr Surg 1998;102:2040-8.

10. Sarifakioglu N, Gokrem S, Ates L, Akbuga UB, Aslan G. The influence of sildenafil on random skin flap survival in rats: An experimental study. Br J Plast Surg 2004;57:769-72.

11. Barral SM, Araujo ID, Vidigal PV, Mayrink CA, Araujo AD, Costa PR. Effects of sildenafil on the viability of random skin flaps. Acta Cir Bras 2011;26:314-9.

12. Khan A, Ashrafpour H, Huang N, et al. Acute local subcutaneous VEGF165 injection for augmentation of skin flap viability: Efficacy and mechanism. Am J Physiol Regul Integr Comp Physiol 2004;287:R1219-29.

13. Wang SP, Lan ZY, Xia W, et al. The effects of vasonatrin peptide on random pattern skin flap survival. Ann Plast Surg 2014;72:94-9.

14. Lawrence WT, Murphy RC, Robson MC, Heggers JP. The detrimental effect of cigarette smoking on flap survival: An experimental study in the rat. Br J Plast Surg 1984;37:216-9.

15. Kaufman T, Eichenlaub EH, Levin M, Hurwitz DJ, Klain M. Tobacco smoking: Impairment of experimental flap survival. Ann Plast Surg 1984;13:468-72.

16. Nolan J, Jenkins RA, Kurihara K, Schultz RC. The acute effects of cigarette smoke exposure on experimental skin flaps. Plast Reconstr Surg 1985;75:544-51.

17. Craig S, Rees TD. The effects of smoking on experimental skin flaps in hamsters. Plast Reconstr Surg 1985;75:842-6.

18. Forrest CR, Pang CY, Lindsay WK. Dose and time effects of nicotine treatment on the capillary blood flow and viability of random pattern skin flaps in the rat. Br J Plast Surg 1987;40:295-9.

19. Forrest CR, Pang CY, Lindsay WK. Pathogenesis of ischemic necrosis in random-pattern skin flaps induced by long-term lowdose nicotine treatment in the rat. Plast Reconstr Surg 1991;87:518-28.

20. Forrest CR, Xu N, Pang CY. Evidence for nicotine-induced skin flap ischemic necrosis in the pig. Can J Physiol Pharmacol 1994;72:30-8.

21. Rees TD, Liverett DM, Guy CL. The effect of cigarette smoking on skin-flap survival in the face lift patient. Plast Reconstr Surg 1984;73:911-5.

22. Goldminz D, Bennett RG. Cigarette smoking and flap and fullthickness graft necrosis. Arch Dermatol 1991;127:1012-5.

23. Heliövaara M, Karvonen MJ, Vilhunen R, Punsar S. Smoking, carbon monoxide, and atherosclerotic diseases. Br Med J 1978;1:268-70.

24. Levine PH. An acute effect of cigarette smoking on platelet function. A possible link between smoking and arterial thrombosis. Circulation 1973;48:619-23.

25. Davis JW, Davis RF. Acute effect of tobacco cigarette smoking on the platelet aggregate ratio. Am J Med Sci 1979;278:139-43.

26. Hawkins RI. Smoking, platelets and thrombosis. Nature 1972;236:450-2.

27. Mosely LH, Finseth F. Cigarette smoking: Impairment of digital blood flow and wound healing in the hand. Hand 1977;9:97-101.
28. Reus WF, Robson MC, Zachary L, Heggers JP. Acute effects of tobacco smoking on blood flow in the cutaneous micro-circulation. Br J Plast Surg 1984;37:213-5.

29. Dintenfass L. Elevation of blood viscosity, aggregation of red cells, haematocrit values and fibrinogen levels with cigarette smokers. Med J Aust 1975;1:617-20.

30. Renaud S, Blache D, Dumont E, Thevenon C, Wissendanger T. Platelet function after cigarette smoking in relation to nicotine and carbon monoxide. Clin Pharmacol Ther 1984;36:389-95.

31. Silverstein P. Smoking and wound healing. Am J Med 1992;93:22S-4.

32. Gallavan RH Jr, Tsuchiya Y, Jacobson ED. Effects of nicotine on canine intestinal blood flow and oxygen consumption. Am J Physiol 1984;246:G195-203.

33. Cordivari C, Misra VP, Catania S, Lees AJ. New therapeutic indications for botulinum toxins. Mov Disord 2004;19(Suppl 8):S157-61.

34. Bhidayasiri R, Truong DD. Expanding use of botulinum toxin. J Neurol Sci 2005;235:1-9.

35. Naumann M, Lowe NJ. Botulinum toxin type A in treatment of bilateral primary axillary hyperhidrosis: Randomised, parallel group, double blind, placebo controlled trial. BMJ 2001;323:596-9.

36. Lipp A, Trottenberg T, Schink T, Kupsch A, Arnold G. A randomized trial of botulinum toxin $\mathrm{A}$ for treatment of drooling. Neurology 2003;61:1279-81.

37. Brin MF. Botulinum toxin: Chemistry, pharmacology, toxicity, and immunology. Muscle Nerve Suppl 1997;6:S146-68.

38. Dolly JO, Ashton AC, Evans D, et al. Molecular action of botulinum neurotoxins: Role of acceptors in targeting to cholinergic nerves and in the inhibition of the release of several transmitters. In: Dowdall MJ, Hawthorne J, eds. Cellular and Molecular Basis of Cholinergic Function. Chichester: Ellis Horwood, 1987:517-35.

39. Morris JL, Jobling P, Gibbins IL. Botulinum neurotoxin A attenuates release of norepinephrine but not NPY from vasoconstrictor neurons. Am J Physiol Heart Circ Physiol 2002;283:H2627-35.

40. Clemens MW, Higgins JP, Wilgis EF. Prevention of anastomotic thrombosis by botulinum toxin $\mathrm{A}$ in an animal model. Plast Reconstr Surg 2009;123:64-70.

41. Davies BW, Lewis RD, Pennington G. The impact of vasodilators on random-pattern skin flap survival in the rat following mainstream smoke exposure. Ann Plast Surg 1998;40:630-6.

42. Kim TK, Oh EJ, Chung JY, Park JW, Cho BC, Chung HY. The effects of botulinum toxin A on the survival of a random cutaneous flap. J Plast Reconstr Aesthet Surg 2009;62:906-13.

43. Werner N, Nickenig G. Sex hormones save our skin: The vascular networking of estrogen. Circ Res 2009;104:135-7.

44. Toutain CE, Brouchet L, Raymond-Letron I, et al. Prevention of skin flap necrosis by estradiol involves reperfusion of a protected vascular network. Circ Res 2009;104:245-54.

45. Coggins CR. An updated review of inhalation studies with cigarette smoke in laboratory animals. Int J Toxicol 2007;26:331-8.

46. Rinker B, Fink BF, Barry NG, Fife JA, Milan ME. The effect of calcium channel blockers on smoking-induced skin flap necrosis. Plast Reconstr Surg 2010;125:866-71.

47. Khouri RK, Angel MF, Edstrom LE. Standardizing the dorsal rat flap. Surg Forum 1986;37:590.

48. Aker JS, Mancoll J, Lewis B, Colen LB. The effect of pentoxifylline on random-pattern skin-flap necrosis induced by nicotine treatment in the rat. Plast Reconstr Surg 1997;100:66-71.

49. Karien RG, Maisel RH. Terazosin blockade of nicotine-induced skin flap necrosis in the rat. Arch Otolaryngol Head Neck Surg 1997; 123:837-40.

50. Eskitascioglu T, Gunay GK. The effects of topical prostacyclin and prostaglandin $\mathrm{E}_{1}$ on flap survival after nicotine application in rats. Ann Plast Surg 2005;55:202-6.

51. Sycha T, Graninger M, Auff E, Schnider P. Botulinum toxin in the treatment of Raynaud's phenomenon: A pilot study. Eur J Clin Invest 2004;34:312-3.

52. Linderoth B, Gunasekera L, Meyerson BA. Effects of sympathectomy on skin and muscle microcirculation during dorsal column stimulation: animal studies. Neurosurgery 1991;29:874-9.

53. van Dielen FM, Kurvers HA, Dammers R, et al. Effects of surgical sympathectomy on skin blood flow in a rat model of chronic limb ischemia. World J Surg 1998;22:807-11. 
54. Yanagiya Y, Yoshimura R, Hori M, Kuwahara M, Tsubone H, Sugano $S$. The influence of chronic sympathectomy on cutaneous blood flow in the rat tail. J Vet Med Sci 1999;61:795-801.

55. Fathi M, Fathi H, Mazloumi M, et al. Preventive effect of botulinum toxin $\mathrm{A}$ in microanastomotic thrombosis: $\mathrm{A}$ rabbit model. J Plast Reconstr Aesthet Surg 2010;63:e720-4.

56. Morris MJ, Elliott JM, Cain MD, Kapoor V, West MJ, Chalmers JP. Plasma neuropeptide $\mathrm{Y}$ levels rise in patients undergoing exercise tests for the investigation of chest pain. Clin Exp Pharmacol Physiol 1986;13:437-40.

57. Morris M, Kapoor V, Chalmers J. Plasma neuropeptide Y concentration is increased after hemorrhage in conscious rats: Relative contributions of sympathetic nerves and the adrenal medulla. J Cardiovasc Pharmacol 1987;9:541-5.

58. Pernow J, Lundberg JM, Kaijser L, et al. Plasma neuropeptide Y-like immunoreactivity and catecholamines during various degrees of sympathetic activation in man. Clin Physiol 1986;6:561-78.

59. Lundberg JM, Hökfelt T. Multiple co-existence of peptides and classical transmitters in peripheral autonomic and sensory neurons functional and pharmacological implications. Prog Brain Res 1986;68:241-62.

60. Stjärne L. Basic mechanisms and local modulation of nerve impulse-induced secretion of neurotransmitters from individual sympathetic nerve varicosities. Rev Physiol Biochem Pharmacol 1989;112:1-137.
61. Pellegrini LL, O'Connor V, Lottspeich F, Betz H. Clostridial neurotoxins compromise the stability of a low energy SNARE complex mediating NSF activation of synaptic vesicle fusion. EMBO J 1995;14:4705-13.

62. Söllner T, Whiteheart SW, Brunner M, et al. SNAP receptors implicated in vesicle targeting and fusion. Nature 1993;362:318-24.

63. Jinsi-Parimoo A, Deth RC. Reconstitution of alpha2D-adrenergic receptor coupling to phospholipase D in a PC12 cell lysate. J Biol Chem 1997;272:14556-61.

64. Tarabal O, Calderó J, Ribera J, et al. Regulation of motoneuronal calcitonin gene-related peptide (CGRP) during axonal growth and neuromuscular synaptic plasticity induced by botulinum toxin in rats. Eur J Neurosci 1996;8:829-36.

65. Matic DB, Lee TY, Wells RG, Gan BS. The effects of botulinum toxin type A on muscle blood perfusion and metabolism. Plast Reconstr Surg 2007;120:1823-33.

66. Kim YS, Roh TS, Lee WJ, Yoo WM, Tark KC. The effect of botulinum toxin A on skin flap survival in rats. Wound Repair Regen 2009;17:411-7.

67. Manchio JV, Litchfield CR, Sati S, Bryan DJ, Weinzweig J, Vernadakis AJ. Duration of smoking cessation and its impact on skin flap survival. Plast Reconstr Surg 2009;124:1105-17. 